\title{
A significant statement: new outlooks on treatment documentation
}

\section{Abigail Duckor, Jan Dariusz Cutajar, Dean Sully \& L. Harald Fredheim}

To cite this article: Abigail Duckor, Jan Dariusz Cutajar, Dean Sully \& L. Harald Fredheim (2016): A significant statement: new outlooks on treatment documentation, Journal of the Institute of Conservation

To link to this article: http://dx.doi.org/10.1080/19455224.2016.1212717

Accepted author version posted online: 28

Jul 2016.

Published online: 28 Jul 2016.

Submit your article to this journal $₫$

Q View related articles $\asymp$

View Crossmark data \lceil 
Publisher: Taylor \& Francis \& Icon, The Institute of Conservation

Journal: Journal of the Institute of Conservation

DOI: $10.1080 / 19455224.2016 .1212717$

\title{
A significant statement: new outlooks on treatment documentation
}

Abigail Duckor ${ }^{\mathrm{a}}$, Jan Dariusz Cutajar ${ }^{\mathrm{a} *}$, Dean Sully and L. Harald Fredheim ${ }^{\mathrm{b}}$ aInstitute of Archaeology, 31-34 Gordon Square, London, WC1H 0PY, UK. Email:

aduckor@gmail.com; d.sully@ucl.ac.uk

${ }^{\mathrm{b}}$ Department of Archaeology, University of York, King's Manor, York, YO1 7EP, UK. Email: leif.freidheim.12@alumni.ucl.ac.uk

*Corresponding author. Email: jan.cutajar.13@ucl.ac.uk

\begin{abstract}
Values-based conservation is an increasingly dominant theme in heritage conservation theory. It is less routine in the application of object conservation practice, where emphasis on the physical fabric of heritage prevails. Materials-based approaches pivot conservation decisions on assessments of object condition. Values-based approaches posit that conservation should seek to sustain and enhance heritage significance rather than arrest physical change. A values-based approach is also one where the value-judgements underlying conservation decisions are made explicit. To reflect this, a new treatment documentation format has been developed at the UCL Institute of Archaeology. The documentation procedure shifts the focal point from condition assessments to statements of significance. Within the professional setting, similar new documentation is being developed for lightbased artworks at Glasgow Museums, Ultimately, using a value-based treatment report, the conservator can be aware of the reasoning behind treatment choices and be better equipped to make decisions that reflect an object's values.
\end{abstract}

Keywords: documentation; significance; values-based; heritage; values; reports

Introduction - background on values-based treatment in conservation

Teaching the conservation of archaeological and museum objects has a long tradition at the University

College London (UCL), Institute of Archaeology (IoA). ${ }^{1}$ Since taught conservation courses first began in the 1930s, conservation has developed within the prevailing intellectual framing of the 
subject. Initially, the course developed as a technical specialism of archaeology, then as an applied material science within archaeology and museology, and more recently as critical practice within heritage studies. ${ }^{2}$ Conservation practice continuously adjusts to changes within the discipline taking place in academic and industrial institutions. ${ }^{3}$ Arguably, one challenge faced by the conservation discipline is to ensure that the every-day tools used in making conservation decisions reflect contemporary ways of understanding the world. ${ }^{4}$

The development of materials-based, values-based, and peoples-based approaches to the conservation of heritage over the past fifty years can be plotted: Table 1 comparatively illustrates their frameworks. ${ }^{5}$

[Table 1 here]

Over the past two decades, in line with developments in conservation theory elsewhere, questions of why we conserve heritage have increasingly been emphasized, alongside the teaching of how the aims of conservation can be achieved. ${ }^{6}$ Significant progress in the discourse of values-based and participatory conservation can be seen in the work of Avrami et al., Clavir, Stovel, Muñas-Viñas, Smith, and Wharton, ${ }^{7}$ which has further enabled the accommodation of broader concepts of heritage into conservation practice than was previously the case. ${ }^{8}$

The shift in focus could be seen as an evolutionary sequence, but more usefully it represents a broadening of the framework of theory and practice in heritage conservation in which these approaches are utilised to differing degrees, depending on the requirements of a particular heritage project. The reframing of conservation in this way encourages greater diversity in conservation practice as it provides the intellectual justification for challenging established norms that can limit what are considered as appropriate solutions to the problems identified in such practice. In so doing, it enables the continuity of established conservation practice, associated with a materials focus, where this is considered to be the most appropriate approach, yet sanctions the incorporation of a community's cultural values into conservation decision-making, where relevant. 
Accordingly, the language and philosophy of values-based conservation has come to dominate the approach to conservation at the IoA. ${ }^{9}$ This shift in emphasis is reflected in the authors' approach to interventive conservation treatments that is taught during practical laboratory sessions. At first, this was effected by adapting existing treatment documentation templates to reflect this change in approach, after which it then became clear that a fundamental overhaul was required. The following discussion describes the process of developing a new format for objects conservation documentation that reflects a change from materials-based to values-based conservation approaches. ${ }^{10}$ This has broader implications for the documentation of interventive conservation treatments in institutions that seek to incorporate such a paradigm shift in the conservation of heritage objects. By briefly focussing on the values-based approach being used to develop documentation for the light-based artworks held by Glasgow Museums, this paper will also indicate the practicalities and benefits of such a shift in an institutional setting.

Making a transition: materials-based to values-based conservation

The ability of conservators to intervene in the material remains of the past and to create something that is meaningful and useful in the present has been at the core of modern conservation practice. It provides a focus for the allocation of resources that are manifest in well-managed, heritage visitor attractions, in well-ordered stored collections, and exhibited objects of museums and heritage institutions. ${ }^{11}$ The adaptation of a scientific discourse to materials-based conservation has been a defining characteristic of the conservation profession and its evolution as a heritage specialism. A set of conservation core values can be linked to foundational documents such as the Athens Charter and the Venice Charter..$^{2}$ These documents prioritized the materiality or monumentality of heritage as the focus for conservation action, and such an approach is based on principles of authenticity, and maintaining the historical and physical context of monuments, buildings, and sites. Thus, any conservation intervention is limited by concepts of anastylosis, minimum intervention, respect for 
historic evidence, avoidance of falsification, preservation of the original, and reversibility of interventions. $^{13}$

The type of conservation associated with this approach is perceived as a technical process, aimed at resolving the instability of physical fabric, in order to preserve it for future generations. Consequently, significance is 'objectively' determined, because values are considered qualities inherent in an object, identifiable by experts. Naturally, this relies upon specialist knowledge of heritage materials and an understanding of how and why these materials change over time. As a result, conservation practice and research has generally been based on an understanding of the physical vulnerability of the conservation object, and the actions required in order to mitigate these changes in the condition of the object. $^{14}$

Claims about the role of heritage within political campaigns for social inclusion and diversity have encouraged heritage professionals to look for the benefits of conservation beyond the stability of heritage material. ${ }^{15}$ The conserved object that results froma conservation process focussed on an essentialized notion of an object, represented only by its material constituents, limits the multifaceted significance of the object and restricts ways of experiencing objects and the past. An acknowledgement that objects have cultural value beyond the materials from which they are made allows us to appreciate that conservation is not undertaken just because materials are damaged, but because cultural value can be maintained and/or revealed. ${ }^{16}$

Values-based approaches to conservation posit that conservation should seek to sustain and enhance heritage significance rather than arrest physical change. Arguably, 'value has always been the reason underlying heritage conservation,' where value can be made to imply cultural significance. ${ }^{17}$ If heritage were not considered valuable, resources would not be allocated for conservation.

Conversely, it may be argued that it is the actions of conservation which create heritage - therefore, not only do we care for heritage because it is valued, it is valued because we care for it. ${ }^{18}$ While all conservation can be considered an expression of values, a values-based approach makes the value- 
judgements underlying conservation decisions explicit. A values-based approach, hence, is based on the assessment of significance of the conservation object. This involves identifying what is valuable about the object and why. Within a materials-based framework, these judgements remain implicit, rendering the justification of conservation decisions difficult to communicate, and the underlying points of contestation challenging to identify. It may well be that value-judgments are implicit in daily practice, however, they are not always explicit in conservation documentation. Thus, there exists the requirement to explicitly emphasise these decisions both in practice and in professional documentation in order to ameliorate the communication of conservation decision-making.

Defining the theory: heritage values and value typologies

1. Heritage values and significance

A values-based conservation framework seeks to incorporate a broad range of opinions within the decision-making process through engagement with multiple stakeholders. ${ }^{19}$ The efficacy of this process is seen within the United Kingdom, where it is evident in the UK Heritage Lottery Fund and Historic England planning procedures. ${ }^{20}$ This has challenged the dominance of the palpable object seen, felt, and understood as the tangible focus of the work of conservators - and forces a reconsideration of the conserved object as the physical product of our work. It has also provided a mechanism for the incorporation of categories of information that were previously made invisible and hidden in the conservation process, and introduced the necessity for heritage conservation to focus on the instrumental benefits of its work beyond the physical quality of the conserved object. This is reflected in the need to have wider demonstrable outcomes as social, cultural, environmental, sustainable, and financial benefits. ${ }^{21}$

In the Burra Charter review process, ${ }^{22}$ decisions are premised on developing an understanding of Cultural significance through physical examination, historical research, and community consultation. ${ }^{23}$ The production of a statement of significance is used to provide a clear reference point from which to consider the impact of proposed conservation actions. ${ }^{24}$ As a tool of heritage management, compiling 
a statement of significance involves extracting the necessary contextual conservation assessments from a comprehensive account of all the cultural values associated with a place/object. The statement flows from value assessments, understood as a summary of the cultural heritage values ascribed by heritage communities.

The recognition that the values of heritage objects change over time has given rise to their identification as social constructs. ${ }^{25}$ This raises the question of who has the authority to determine significance. The ability to understand the transient nature of significance in a heritage place/object is limited by the time, resources, and skills available in the process. However, consultation processes should seek to incorporate commensurate and converging values, and emphasise the plural and often contradictory nature of significance, as interpreted by various stakeholders. The statement of significance, leading to a conservation assessment, and conservation management strategy, have become standard tools for the management of landscapes, sites, and heritage places, and should be explicitly incorporated into the conservation of museum objects and collections. If authority is to be shared and multiple perspectives on significance sourced, efficient mechanisms for accomplishing this must be developed for inclusive values-based approaches to be feasible in practice. ${ }^{26}$ As recognised heritage experts who regularly alter heritage objects, conservators hold considerable authority over who is given a voice and which interpretations of significance are legitimised and imposed on objects through remedial and preventive treatments. It is important that conservators recognise the responsibility this authority entails, as conservation decisions facilitate selected current and future uses of objects, while restricting others. ${ }^{27}$

In response to recent critiques of values-based approaches, ${ }^{28}$ Fredheim and Khalaf have developed a framework for identifying and communicating significance that is based on Stephenson's Cultural Values Model (Fig. 1) and a review of established value typologies for heritage. ${ }^{29}$ Their framework reflects current debates in critical heritage studies by accommodating symmetrical and dialogical interpretations of heritage. ${ }^{30}$ 
[Fig. 1 here]

Unlike established values-based approaches, such as Historic England's (then English Heritage)

Conservation Principles, ${ }^{31}$ which suggest that values should be linked to tangible heritage attributes, Fredheim and Khalaf argue that all significant features, including intangibles, must be identified and their values made explicit. ${ }^{32}$ Their adoption of Stephenson’s Cultural Values Model allows practices and relationships to be identified as features of heritage objects alongside physical forms in an effort to facilitate the de-colonization of heritage and accommodate a full range of heritage features and heritage values. Hence, the framework cuts across disciplinary boundaries and facilitates the integration of professional and non-professional values, ${ }^{33}$ which tend to be marginalized by established typologies. ${ }^{34}$ While conservation decisions will inevitably prioritize some aspects of value over others, these decisions should be made and negotiated explicitly, rather than implicitly by frameworks and methods that privilege certain interpretations. By documenting these decisions in a values-based treatment report, a conservator in the future can be aware of the reasoning behind treatment choices and better equip themselves to make decisions that appropriately reflect an object's values.

\section{Redefining damage and valorisation}

An assessment of an object's condition routinely provides a focal point for decision-making in the materials-based conservation process. Physical status, however, is never an objective reference point discernible in the materiality of those objects, nor is the assessment of condition an objective process of description, rather both prompt a series of judgments constructed within the prevailing intellectual framing of the questions posed. So, rather than a fixed reference point, the notion of the object's 'condition' is contextual and understood in relation to other criteria, such as function, purpose, expectation, and use.

Damage can be understood as undesirable change. In light of the realization that material deterioration can be considered desirable, damage and deterioration must be disentangled. ${ }^{35}$ As the 
values-based nature of damage becomes recognized, ${ }^{36}$ damage can be defined as changes resulting in the loss of significance. ${ }^{37}$ For example, graffiti may be considered as both 'street art' or 'vandalism'. While the values-based paradigm does not judge such interpretations as right or wrong, it does provide a framework within which contrasting perspectives can be rationalized and critiqued, which a purely materials-based framework cannot. Redefining damage has implications for assessments of condition, which are crucial to decision-making for object conservators.

Materials-based approaches pivot conservation decisions on professional assessments of an object's condition. Conservation measures are enacted in order to mitigate past damage and reduce the risk or rate of further damage in the future. An object in good condition can therefore be understood as one that is not significantly damaged and is resilient to identified 'agents of deterioration' ${ }^{38}$ It is increasingly clear that professional judgements of object condition are not objective, as research has demonstrated an alarming lack of consensus amongst different assessors. ${ }^{39}$ This can be explained by recognizing that assessing condition not only involves identifying material change and vulnerability, but also implicit judgements about what is significant about an object and the extent to which physical changes impact upon its significance. If condition is a measure of damage, and damage a measure of significance lost, condition cannot be assessed without first assessing significance. Separating the assessment of condition from its impact on cultural significance suggests that 'condition' is something that is real and out there in the world to be revealed by our investigations. Rather, an assessment of condition should be seen as 'damage' to cultural significance; it cannot stand as a pseudo-objective description of physical fabric. ${ }^{40}$

Despite their prominence in values-based approaches in the management of heritage sites over the past half century since the original Burra Charter, values and significance have remained poorly understood. ${ }^{41}$ While conservation has tended to focus exclusively on mitigating damage and minimizing risk, new objects and object features continue to be identified as heritage. It follows that significance can both increase and decrease i.e. heritage can both be damaged and valorized. 
Additionally, the continued recognition by heritage professionals, including some conservators, that heritage does not belong exclusively to experts, calls for increasingly reflective professional practice that mitigates damage and facilitates valorization. These aspects of practice should be transparently reflected and clearly communicated through the appropriate means of documentation.

Theory to practice: treatment documentation at the UCL IoA

In response to the tensions noted above, a documentation project was conducted by students in the UCL IoA conservation laboratory in order to realign conservation treatment documentation to reflect a values-based approach. A pilot project for a new documentation system was co-ordinated by the authors during the 2014-15 academic year. This required a redesign of existing conservation documents for treatment proposals and treatment reports, and the associated guidance documents.

\section{Impetus for transition}

The aims of the project were clearly defined from the outset and extracted from the discussions presented in the above sections. In addition to targeting a definitive move towards feasibly implementing values-based documentation, other goals driving the project involved creating an effective learning tool, improving workflow and communicating conservation decision-making. The format of the conservation documentation was determined by the use for which it was intended. As the new forms were to be used within an academic setting, they were optimised to permit conservation students to apply a theoretical understanding of values-based approaches to the practical treatment of conservation objects. The forms were designed to guide a conservator's decision-making through a values-based approach. This would streamline the information gathering and recording process during an object treatment, whilst making each step in the process explicit.

\section{Outline of documentation format}

The new documentation templates developed at the IoA require students to identify what is significant about an object in a formalized statement of significance, and subsequently to identify how significance has been damaged or is likely to be damaged in the future via a condition assessment. 
Only features about the object identified as significant in the statement of significance can be included in an assessment of object condition, since damage reflects a constraint to cultural significance. ${ }^{42}$

The compiling of a statement of significance and condition assessment enable the production of a statement of conservation from which treatment options and proposals can be developed. Once treatment is complete, students are asked to demonstrate in the treatment report how the performed object treatment has enhanced significance and improved condition, or otherwise. By documenting conservation in this way, conservators can critically evaluate their own value-judgements and communicate the conservation treatment as a cultural process, beyond its mere technical and scientific aspects.

Overall then, the coupling of statement of significance and condition assessment lay out the treatment targets, manifested in the statement of conservation, in a clear and concise format. As a result, students are able to assess the relative aspects of an object's significance and its priorities for treatment, in a more straightforward fashion. The clarity of the statements produced reduces the probabilities of overlooking significant tangible and intangible features of an object. Consequently, the final treatment decision may target aspects of significance (especially intangible features) which otherwise may have not been addressed using an exclusively materials-based approach. Perhaps more importantly is the realization that even if materials- and values-based considerations result in similar or exact treatment conclusions, the overall recording of the treatment using the values-based documentation should be richer in contextual information and thus arguably higher in quality. While the documentation format presented in this paper does not always alter the outcomes for treatment, it categorically reflects a change in the means of recording these outcomes such that they are contextually substantiated and accessible to future conservators.

Having described the theory and objectives for the values-based methodology presented here, the documentation templates for conservation treatment proposals and conservation treatment records, posited around statements of significance, are presented in Figs. 2 and 3 and are detailed in the

following sections.

[Fig. 2 here]

Conservation treatment proposal: planning a values-based treatment

1. Object contextualization and identification 
The context for each object treatment provides the operating framework for the treatment. The aims of the conservation treatment first need to be identified and understood. Therefore, the significance of the individual object needs to be considered in the context of its intended future use. The proposed uses and future storage conditions of the object need to be considered in order to determine the intention of the treatment and, hence, develop an appropriate treatment solution according to established professional guidelines.

In order to develop a sufficient understanding of objects to effectively conserve them, students at IoA are encouraged to consult stakeholders, including the owner, other heritage professionals and relevant specialists. The involvement of such stakeholders, connected variously through professional, legal, cultural, and emotional relations to the object, is essential in order to provide justification for any conservation decision. In turn, these consultations directly influence the ability of the conservator to significantly alter an object during its conservation, precisely because of the limitations imposed on them by the extent of the consensus established in dialogue with this diversity of people.

This first stage of contextualization of the object within the conservation laboratory leads onto a more in-depth analysis of the object. Here, students are requested to input a description of the object's significant attributes. These can include identification of materials, manufacturing techniques, colour measurements, intangible features, and so on. In order to ensure the production of concise and relevant information, only those attributes identified by the student in the statement of significance, condition assessment or treatment recommendations are included.

\section{Statement of significance}

The assessment of cultural significance, i.e. the statement of significance, provides an essential focus for the production of an appropriate conservation treatment plan. Thus, the conservation treatment should be charged with revealing, regaining, or enhancing the cultural significance of the conserved object. The model used at the IoA for assessing and communicating the significance of objects builds on frameworks developed elsewhere, ${ }^{43}$ but has been designed specifically to accommodate a large 
range of types of heritage, to integrate expert and non-expert interpretations, and facilitate the changing nature of values over time. In this model, the values of each significant feature are considered and classified according to importance as evidence, by association, for sensory stimulation and/or by performing a function. Following this, aspects of value are thus grouped under the headings of i) Evidentiary, ii) Associative, iii) Sensory and iv) Functional significance (see Table 2). Such a classification arguably aids the identification of how physical change affects significance.

[Table 2 here]

Furthermore, these layers of significant values can be further detailed using more specific descriptors such as: historical, informational, educational, scientific, research, commemorative, symbolic, social, spiritual, communal, sentimental, cultural, aesthetic, auditory, scent-, taste- and touch-related. Having developed a statement of significance, students may then proceed to identify the ways in which it has been damaged in the past and how it is likely to be damaged in the future. Both the relevant aspects of the object's cultural value (the statement of significance) and physical attributes (the object description) should be identified in relation to aspects of damage. Past or potential changes that do not relate to the identified significance should not be considered damage and need not be targeted by the documentation or treatment. For example, one low-fired Ancient Egyptian ceramic treated at the IoA was received in a fragmentary state. Due to the abundance of identical and complete vessels within the donor's collection, and after discussion with the donor, it was decided that the artefact's layer of evidentiary significance, represented by its embodied research and educational values made explicit by its cross-section, outweighed its sensory significance from any aesthetic or historical perspective. This determination of primary significance for the object signified that its fragmentary nature was not considered detrimental, but rather as beneficial. The state of fragmentation, representing a past change in the object's materiality, was not evaluated as damage to the physical material as this did not relate to its identified evidentiary significance. As a consequence, the treatment design focussed on enhancing the information that could be extracted from the 
ceramic's matrix, rather than the object's repair. However, such identifications of 'damage' and significance - and damage to significance - also mean that it may be necessary to review the statement of significance following the assessment of condition, and vice versa, as in a continuous, iterative process.

It should be noted that the process of categorisation is only ever partial and is incomplete. ${ }^{44}$ Critical heritage researchers have drawn attention to the ways in which the heritage categories it employs are not 'natural', but actively formed within a system of particular cultural values. ${ }^{45}$ For example, valuesbased conservation approaches rely on standardized, semantic categories to assess cultural significance. This can perpetuate the hierarchical power relationships that are evident in the making of 'authorized heritage'. Heritage meaning, therefore, always derives from labelling and classification that follows a specific epistemological framework.

\section{Statement of conservation and treatment plans}

The aims of the conservation treatment must be clearly stated in the conservation proposal documentation. The statement of conservation thus describes what the treatment is designed to achieve. This differs from a treatment proposal, per se, which seeks to define how this is going to be conserved. Any proposed conservation action can then be reviewed by comparing the statement of conservation with the statement of significance to ensure that the key aspects of object significance are conserved by the treatment. The type of statement of conservation might be as follows:

The purpose of conservation is to conserve evidence of the object's period of archaeological burial. The purpose of conservation is to conserve evidence of the object's unique method of manufacture. The purpose of conservation is to conserve evidence of the object's extensive use. While these may present overlapping aspects that are not mutually exclusive, nonetheless, choices may have to be made to prioritise one aspect over another. For example, deposits from the archaeological burial of an object might be covering the use-marks present on the object's surface. In this manner, these two aspects are overlapping, literally, one over the other. If the statement of 
significance dictates that the burial context of the object outweighs its functionary evidence, then the deposits may be preserved and both layers of significance physically conserved. Should the statement of significance favour the use-marks over the burial deposits, then these may be completely or partially revealed whilst documenting the measurable loss of archaeological accretions. From this perspective, and in unison with the statement of significance, the statement of conservation acts as a toolkit for recording what the treatment priorities are with respect to the selected treatment.

Essentially, the statement of conservation is a summary of expectations and goals for the conserved object. This relates the expected treatment outcome to the impact on the significance and condition of the object and, hence, identifies ways of making cultural significance understandable in the fabric of the object.

Consequently, on the basis of the completed assessments of pre-treatment significance and condition, and in light of the context of the treatment, students may proceed to formulate a formal treatment plan. These fields require the demonstration of an awareness of the broad range of options (from minimal to maximal intervention), implications of the treatment process, and most importantly, justifications for treatment decisions in light of the statement of significance. When an interventive treatment is proposed, the effects of the applied conservation materials/treatments/techniques on the object materials must be fully considered in relation to the impact on the cultural significance of the object.

[Fig. 3 here]

Conservation treatment report: reflecting on values-based decisions

The conseryation treatment report builds upon and reflects the structure of the conservation treatment proposal. Any future conservator consulting the record should be able to follow the decision-making processes which took place during treatment. In addition to being a record of treatment details, the treatment report is structured so that students may reflect on induced changes in significance as well as evaluate their overall results in light of the statement of conservation. 


\section{Pre- and post-treatment considerations}

The treatment report explicitly communicates the alterations in object significance as a direct consequence of treatment. This process allows an evaluation of treatment success or failure in relation to the statement of conservation. It also permits the conservator to identify how specific values have been altered, positively or negatively, as a consequence of specific changes in the object's physical condition. Such deliberations provide the opportunity to detail the implications of treatment on the overall object significance, whilst reflexively assessing value-judgments.

\section{Treatment details and evaluation}

The treatment report is a review of the performed treatment, structured in order of the increasing extent of intervention up unto the final phases of display and storage. In detailing the various stages of the object treatment, students are also prompted to explain their choice of technique and materials, again in an effort to make conservation decisions explicit to the reader. The 'Treatment Justifications' section (Fig. 3) thus denotes the transient nature of conservation techniques and materials, as they are temporally specific, being bound by both technology and advocated practice. This in turn continues to echo the transitory nature of significance and the necessity of documenting such decisions. The justifications are also contextually complemented by a reflexive and formative exercise towards the final section of the treatment report, where a personal evaluation of the overall treatment is given with respect to fulfilling the statement of conservation and respecting the priorities described within the statement of significance.

The next transition: using values-based treatment documentation in a professional setting At the IoA, the formative aspects of documentation are more pronounced: as an institute concerned with training new conservators, this emphasis is not surprising. As a pedagogical tool, the guidelines for documentation teach a framework of assessment and a series of steps toward proposing and justifying treatments. Serving as a formative foundation, the values-based methodology employed at the IoA becomes a cornerstone upon which other conservation processes can be based. Students training within the IoA conservation programme are required to engage with this methodology and, as 
a consequence, this has the potential to become a practical philosophy in conjunction with professional conservation practice. A multitude of professional conservators have most likely established a values-based approach to treatment decision-making. However, it is crucial not only to have this approach implicit whilst making decisions, but moreover to make it explicit in documentation. In such manner, the treatment choices and the context in which they are made are preserved for the future conservator.

Within a professional setting, it is conceivable that the level of detail in the IoA forms are not logistically feasible. Not only does a professional conservator battle with the stringencies of time and resources dedicated to documentation, but also with those wider demands of the institution for which they work. Every institution has limitations when it comes to availability of funding, supplies, space and coordination with colleagues - thus only a certain amount of time can be devoted to documentation. While the authors understand that such formal pre-treatment documentation will not necessarily be required in professional conservation practice, it is arguably the ability to explicitly approach conservation within a developed values-based framework that will provide the foundation for the execution of informed conservation treatments. ${ }^{46}$ There remains the question of whether the UCL IoA documentation templates could be useful in contemporary professional and institutional contexts, and the following reflection describes the possibility of transferring this approach from its educational setting.

Documentation of light-based sculptures at Glasgow Museums

Currently, an exploration of how the values-based methodology can be applied to documentation is being undertaken at Glasgow Museums. Under the supervision of Stephanie de Roemer (conservator of (3-D art) sculpture/installation art), a new documentation format modelled on a values-based approach is being created for the Sculpture Conservation Department's care of contemporary lightbased artworks 


\section{Conservation considerations for light-based sculpture}

Light-based media pose many new questions for conservation documentation. As soon as new lighting technology becomes available, it is being manipulated in contemporary art - equally as fast, this technology is becoming obsolete due to changes in manufacturing and regulations. ${ }^{47}$ Not only do the tangible aspects of an artwork need to be considered, such as their electrical components, but also the intangible aspects, such as the visual appearance of the artwork within a certain interior. These latter intangibles may be just as important to the original artistic intent. such that both the intangible and tangible aspects of a light-based work are vulnerable to loss without proper documentation. ${ }^{48}$ Recording the specific electronic components used in a light sculpture may appear to be the only way to mitigate against the inherent obsoleteness of lighting technology. It should be acknowledged that the changing use of materials employed in contemporary art is no different from the changes in materials that have occurred throughout the ages historically in art. ${ }^{49}$ Following a values-based approach, it can be understood that often the more important aspect of the artwork is the effect created with this technology, rather than the material components of the object medium itself.

Undeniably, it is still possible for the technological aspects of a piece to be the most significant to the work. Understanding the technology, or the material, and its risk of obsolescence in this case would be of the utmost importance in preserving the object's values. Often, in the conservation of technology-based artworks, a balance between the historic authenticity of the material and the intended operation is required, ${ }^{50}$ In some instances, one may have to accept the inherent ephemeral nature of a light artwork. Understanding this aspect of an object's significance is still valuable to the conservator and for the institution they work for. This information will affect the long-term use and maintenance costs associated with the piece and should be taken into account when acquiring these artworks if it is possible to do so. For some light technology, such as light-emitting diodes (LED), the replacement of components is dependent on the manufacturer. If the LED manufacturer of a certain work is no longer available, then it can be assumed that a completely new LED will eventually need 
to be made for the work to function in the long term. This is an added cost that would ideally be factored in before acquisition, as would the time spent in both negotiation and agreement with the artist.

\section{Outline of the documentation format at Glasgow Museums}

Recording values in documentation is not new in contemporary art conservation theory, especially in relation to time-based media, installation, performance and conceptual art. ${ }^{51}$ By looking at how significance is identified and documented for contemporary art and what has been done at UCL, it is possible to make a practical adaptation for light-based works. In an institutional setting, this can be effected by combining both the practical and theoretical needs of the collection. The practical needs include completing an inventory of the light technology used in the collection, creating a material archive of new and old replacement components and, in an ideal setting, organizing a maintenance schedule. The theoretical aspect involves documenting the object's significance. The four groups of heritage values determined for the UCL documentation forms (evidentiary, associative, sensory and functional) can arguably be used to create a statement of significance that takes into account artist intentions, how the piece appears in the display environment, and how the technology used relates to the historical context in which the piece was created. With this information, one can then determine how the components of the sculpture are important to the overall significance of the piece and determine what elements are of high or low priority for care management.

The collective information for the inventory and for the statement of significance are not determined by the conservator alone, but with help from the curator, through contact with the artist and by those with specialist skills, such as an electrician. Through collaboration, the conservator can thereby gather the necessary information in order to maintain the artist's original intent throughout treatment and display.

As a hypothetical example, if the statement of significance reveals that the colour of the light bulb is important to the work's significance and the inventory reveals that the there is no replacement 
component, then the time and resources of the conservator will be spent trying to find a replacement bulb or someone with specialist skills that can make such a bulb of the exact same colour and intensity. Once accomplished, this may then trigger and justify the decision to remove the current working bulb, and to replace it with the acquired display copy, in order to keep a working original in the material archive. ${ }^{52}$ In the case where the conservator cannot find an exact light bulb replacement, the statement of significance may help determine what it is about the light bulb that is important for maintaining the original artistic intent, such as wattage, colour temperature and shape. Through recording not only what the conservation action was but why it was completed, the future conservator will be able not only to understand what decisions were made, but the context in which they were made.

3. Evaluating the professional approach

In establishing a professional application of values-based documentation, there are still some considerations that need to be addressed. Amongst these deliberations are questions about the feasibility of being able to determine what is considered necessary information, the possibility that the artist's intended impact is unknown and the capacity of such information to be transferred to a database. As highlighted by exemplifying the UCL IoA forms, the success of implementing this methodology lies in the ability to reflect changes in context and shifts in focus beyond the physicality of the original object. In the same manner as the UCL IoA forms, it is paramount to record the current understanding of context to better inform the future conservator on the decision-making process.

Understanding an object's significance is important not just for the conservator but also for the needs of the museum. Through assessing an object's values and composing a statement of significance, there is a clear justification for the choice in treatment or even the decision not to undertake interventive measures. Composing a statement of significance has demonstrable outcomes by aiding the museum in understanding where the values of an object lie. This could relate to such values as social, cultural, environmental, sustainable or financial benefits - all of which have implications on 
how an object functions for the museum and the long-term values of the object. For the conservator, this has additional implications for how their time and resources are discernibly allocated.

\section{Conclusion}

The object-centric focus of the conservation process has provided a unique method of investigation that can contribute to the debate about the past and the way it is understood in the present. The physical examination of the heritage object during investigative conservation can expose traces of past practice within the object itself. This has the potential to reveal social relationships around the manufacture and use of objects, further made evident through decisions about the conservation and presentation of heritage objects. The assumption of this paper has been that the tools, skills, and knowledge associated with conservation work need to move beyond the scientific and technical aspects of the work to consider the cultural interactions that are effected by the processes that are used to care for cultural heritage. This is the concept of cultural significance that has been established as a mechanism for incorporating human values into conservation decision-making and the careful management of change.

In effect, the shift from materials-based to values-based conservation need not necessarily require dramatic changes to established conservation strategies. Nevertheless, the values-based paradigm does provide a framework for making and communicating conservation decisions that raise a series of implications for conservation practice. While the assessment of cultural value and significance does, perhaps, provide a less objective foundation than scientific assessments of material properties, the values-based paradigm offers a framework for conservation that avoids the increasingly unsteady grounding of concepts such as 'revealing the original object,' 'minimum intervention,' 'reversibility' and material-based interpretations of 'damage.'

Values-based conservation is well established in contemporary theories of conservation. The documentation templates developed at the UCL IoA are an example of how values-based conservation can be feasibly implemented within a practical setting by shifting documentation emphasis to a clear 
statement of significance, complemented with treatment justifications, and accounting for the tangible and intangible aspects of an object. The holistic understanding this generates may drive treatments in different directions as opposed to a purely materials-based approach or it may serve to further justify and succinctly communicate the conclusions reached by the latter.

Ultimately, this documentation system needs to be adapted for professional use in order to provide a practical foundation for students as they become practicing conservators. A values-based approach helps reflect the necessary shift in heritage conservation to focus beyond the physical attributes of objects - this is apparent in the conservation of contemporary artworks where there is an inherent or intentional loss of material, but is also relevant to the preservation of all heritage objects. Since cultural values are implicitly important for an object, conservation should explicitly reflect a concern for these values in their documentation, treatment and allocation of time and resources.

\section{Acknowledgments}

The authors would like to thank Glasgow Museums, in particular Stephanie de Roemer, for their cooperation, the 2014-2016 class of UCL MSc students for participation in the project, as well as all the UCL tutors and supervisors for their continuous support. Please note that Abigail Duckor's research programme at Glasgow Museums has been funded in part by the June Baker Award.

\section{Une déclaration significative : de nouvelles perspectives sur la documentation du traitement}

La théorie de la conservation-restauration du patrimoine se base de plus en plus sur le thème des valeurs. Dans le domaine de la conservation-restauration des objets, où l'on souligne la matérialité des objets, ce changement est moins ressenti. Une approche fondée sur la matérialité exige des décisions prises en fonction d’une évaluation de l'état des œuvres. Par contre, une approche fondée sur la théorie de valeurs exige le maintien et l'amélioration de la signification des objets plutôt que simplement l'arrêt de la dégradation des œuvres. Cette approche-ci demande aussi que les décisions 
prises à base de valeurs soient explicites. En réfléchissant à cette philosophie, un nouveau format de documentation des traitements a été développé par l’Institut d'Archéologie à l’UCL. Cette procédure voit l'accentuation de la documentation changer l'évaluation de l'état de l'objet au profit vers sa signification. Dans un cadre professionnel, aux musées de Glasgow, un système similaire de documentation est en train d’être développé pour évaluer des œuvres d’art à base de lumière. Finalement, en utilisant un rapport de traitement fondé sur la théorie des valeurs, le conservateurrestaurateur devient conscient du raisonnement derrière les choix pris pendant un traitement et, en plus, peut prendre en toute confiance des décisions qui reflètent les valeurs des objets.

\section{Una declaración significativa: nuevas perspectivas en la documentación de tratamiento}

La conservación apoyada en valores es un tema cada vez más dominante en la teoría de la conservación del patrimonio. Es menos habitual en la aplicación de prácticas de conservación de objetos, donde prevalece el énfasis en la estructura física del patrimonio. Los enfoques que tienen fundamento en lo material han centrado las decisiones de la conservación en la evaluación de las condiciones de los objetos. Los enfoques afirmados en los valores plantean que la conservación debe tratar de mantener y mejorar la importancia del patrimonio en lugar de detener su cambio físico. Un enfoque basado en valores es también aquel donde los juicios de valor que subyacen a las decisiones de la conservación, se hacen explícitos. Para reflejar esto, un nuevo formato de documentación del tratamiento se ha desarrollado en el Instituto UCL de Arqueología. El procedimiento de documentación desplaza el punto focal de la evaluación de las condiciones a las declaraciones de significación. En el ámbito profesional, nueva documentación similar está siendo desarrollada en los museos de Glasgow para obras de arte con base en la luz. En última instancia, con el uso de un informe de tratamiento apoyado en los valores, el conservador puede ser consciente del razonamiento detrás de las opciones de tratamiento y estar mejor equipado para tomar decisiones que reflejen los valores de un objeto.

„ Eine deutliche Aussage: neue Perspektiven auf Behandlungsdokumentation” 
Werte bezogene Methodik als Basis für die Orientierung und Entscheidungen zur Intervenierung ist ein zunehmender Ansatz in der Praxis der Restaurierung und Konservierung von zeitgenössischen Kulturgütern. Die Angehensweise dieses Modells erscheint relative neu im Gebrauch der Bewahrung von historischen Objekten, wo die Wertebestimmung und darauf folgende Intervenierung auf den Erhalt des physikalischen Materialwertes basiert. Die Voruntersuchung zum etablieren des materiellen Zustandes, fokussieren hierbei auf der Beschreibung und Erfassung des greifbaren Materials und nicht wie in dem hier erwähnten Modell abstrakte und nicht quantifizierbare Werte. Ein

Konservierungsfervahren, das die Erhaltung der nicht matriellen Werte zum Ziel hat, erfasst den Gesammtwert eines Objektes als Kulturerbe zusätzlich zu den greifbaren Materialwerten. In der Methodik der Wertbeschreibung werden diese identifieziert und klar dargestellt, wie in dem von der UCL Institute of Archaeology entwickelten Format zur Dokumentation von Wertbeschreibungen von Objekten. In einem Beispiel der Praxis wird die Methodik zur Erfassung von licht-speziefischen Kunstwerken in der Sammlung der Modernen und Zeitgenössischen Kunst der Glasgow Museen angewendet, und getestet inwieweit dieser Ansatz bei der Erfassung von immateriallen media, so wie Licht, anzuwenden ist und zur langfristigen Erhaltung performatiever Werte solcher Kunstwerke beiträgt.

一个重要声明:保存修复档案的新前景

在文化遗产保护理论中，基于价值的保存修复逐渐占据了主导地位。它在文物保存修复实践中 的应用较少，但在物质结构型的文化遗产里却很普遍。基于物质的方法是依据物质状态评估而 做出保存修复的纼定。基于价值的方法认为保存修复应设法维持和提高遗产的意义，而非仅仅 停止物理上的衰败。人们还可以通过基于价值判断的方法更为明确地做出保存修复的决定。为 了反映这一点, UCL考古研究所设计了新的保存修复档案格式。档案步骤焦点从状态评估转移 到意义陈述上来。在专业领域内，相关人员正在为格拉斯哥博物馆光基艺术品开发类似的新档 案。归根结底, 使用基于价值的保存修复报告可以使修护师认识到处理方案选择背后的原因, 并且有助于做出反映文物价值的决定。 


\section{Biographies}

Abigail Duckor has recently graduated from the MSc in Conservation for Archaeology and Museums at University College London. Her previous degrees include the MA in Principles of Conservation, also from UCL, and a BA in Art History and Fine Art (Summa Cum Laude) from SUNY New Paltz. As part of her MSc degree, she recently participated in two internships, one at the Oxford University Natural History Museum and one with Glasgow Museums. Her dissertation for this degree assesses the development of values-based treatment documentation for contemporary light-based artworks. Jan Dariusz Cutajar has recently graduated from University College London, having read for an MSc in Conservation for Archaeology and Museums. He has also completed his MA in Principles of Conservation at the same institution, where he first became exposed to values-based conservation theory. He also has a BSc (Hons.) (Melit.) in Chemistry from the University of Malta. As a graduate student, Jan has had work experience with Cliveden Conservation Workshops Ltd as well as the National Trust, specifically at Knole House during the 'Inspired by Knole' project. Aside from valuesbased conservation, his other interests include sustainable conservation practice.

Dr Dean Sully is currently Lecturer in Conservation at University College London, Institute of Archaeology where he coordinates the MSc in Conservation for Archaeology and Museums. He joined UCL in 2000, after studying conseryation at UCL, and working as a conservator for the National Heritage Board (Singapore), the Museum of London, the British Museum, and Monmouthshire District Council Museum's Service. Since 2001, he has been a Conservation Advisor for the National Trust. His PhD research focused on the application of peoples-based conservation to conservation practice.

L. Harald Freidheim holds Principles of Conservation (MA) and Conservation for Archaeology and Museums (MSc) qualifications from University College London. He is currently a $\mathrm{PhD}$ candidate at the University of York investigating the sustainability of heritage stewardship communities, in collaboration with the Council for British Archaeology. He is especially interested in documenting the 
benefits of inclusive/public practice and in re-negotiating the boundaries of professional and community responsibilities and expertise. In the past, his research has focused on the appropriate use of heritage, the concept of acceptable damage and how values-based conservation policies can be applied to ‘living’ heritage contexts.

\section{Contact addresses}

Abigail Duckor, Jan Dariusz Cutajar, Dean Sully Institute of Archaeology

31-34 Gordon Square

London WC1H 0PY

UK

aduckor@gmail.com; jan.cutajar.13@ucl.ac.uk; d.sully@ucl.ac.uk

\section{Harald Freidheim}

Department of Archaeology

University of York

King's Manor

York

YO1 7EP

UK

leif.freidheim.12@alumni.ucl.ac.uk;

1 cf. Ione Gedye, 'Forty Years of Conservation at the Institute,' in Recent

Advances in the Conservation and Analysis of Artifacts, ed. James Black (London: Summer Schools Press, 1987), 16-19; Elizabeth Pye, Caring for the Past: Issues in Conservation for Archaeology and Museum (London: James \& James, 2001).

2 Dean Sully, 'Conservation Theory and Practice: Materials, Values, and People in Heritage Conservation,' in The International Handbook of Museum Studies Volume 4. Museum Practice:

Critical Debates in the Museum Sector 4, ed. Conal McCarthy (Sydney: John Wiley \& Sons, 2015), 293-314.

3 See, for example, Elizabeth Pye and Dean Sully, 'Evolving Challenges, Developing Skills,' The Conservator 30, no. 1 (2007): 19-37; and Conservation: Principles, Dilemmas and Uncomfortable Truths, eds. Alison Richmond and Alison Bracker, (London: Butterworth-Heinemann, 2009).

4 Pye and Sully, Evolving Challenges, Developing Skills'; Jonathan Ashley-Smith, 'The Basics of Conservation Ethics,',Richmond and Bracker, Conservation: Principles, Dilemmas and Uncomfortable Truth, 6-24.

5 Sully, 'Conservation Theory and Practice,' 299

6 Pye, Caring for the Past: Issues in Conservation for Archaeology and Museum; Pye \& Sully, 'Evolving Challenges, Developing Skills.' 
7 Erica Avrami et al., Values and Heritage Conservation: Research Report (Los Angeles: Getty Conservation Institute, 2000); Mirim Clavir, Preserving What is Valued; Museums, Conservation, and First Nations (Vancouver: UBC Press, 2002); H. Stovel, 'Top-down and bottom-up management,' ICCROM Newsletter 30 (2004): 16-17; Salvador Muñas-Viñas, Contemporary Theory of Conservation, (London: Butterworth-Heinemann, 2005); L. Smith, Uses of Heritage (Oxon \& New York: Routledge, 2006); and Glenn Wharton, The Painted King Art, Activism, and Authenticity in Hawai'I (Honolulu: University of Hawai'i Press, 2012).

8 Sully, 'Conservation Theory and Practice.'

9 Two IoA-related publications with such an approach are 'Pye, Caring for the Past; Decolonising Conservation: Caring for Maori Meeting Houses Outside New Zealand, ed. Dean Sully, (Walnut Creek: Left Coast Press, 2007); Dean Sully and Isabel Pombo Cardoso, 'Painting Hinemihi by Numbers: Peoples-based Conservation and the Paint Analysis of Hinemihi's Carvings,' Studies In Conservation 59, no.3 (2014): 180-193; see also Sully, 'Conservation Theory and Practice.'

10 For more on values-based conservation practice vis-á-vis other approaches of conservation $c f$. Sully, 'Conservation Theory and Practice.'

11 See, for example, Muñas-Viñas, Contemporary Theory of Conservation, 89; Sully, 'Conservation Theory and Practice.'

12 International Council on Monuments and Sites (ICOMOS), The Athens Charter http://www.icomos.org/en/charters-and-texts/179-articles-en-francais/ressources/charters-andstandards/167-the-athens-charter-for-the-restoration-of-historic-monuments(London: ICOMOS UK, 1931); ICOMOS, The Venice Charter, 1964 http://www.icomos.org/charters/venice_e.pdf (both accessed June 5th, 2016).

13 Clavir, Preserving What is Valued, 43; Frank Matero, Kecia L. Fong, Elisa Del Bono, and Mark Goodman, 'Archaeological site conservation and management. An appraisal of recent trends', Conservation and Management of Archaeological Sites, 2 (1998): 129-142; Muñoz-Viñas, Contemporary Theory of Conservation; Andrew Oddy and Sara Carroll, Reversibility - Does it Exist? (London: British Museum, 1999); Smith, Uses of Heritage, 21; Susan M. Pearce, Archaeological Curatorship (London: Leicester University Press, 1990), 106.

$14 c f$. Dean Sully, 'Conservation Theory and Practice: Materials, Values, and People in Heritage Conservation', in Museum Practice, vol. 2 of The International Handbooks of Museum Studies, ed. Conal McCarthy, (New York: John Wiley \& Sons, 2015); Sully, 'Conservation Theory and Practice.'

15 See, for example, Samuel Jones and John Holden, It's a Material World: Caring for the Public Realm (London: DEMOS, 2008); Sully, 'Conservation Theory and Practice.'

16 Sully, 'Conseryation Theory and Practice.'

17 Assessing the Values of Cultural Heritage: Research Report, ed. Marta de La Torre, (Los Angeles: The Getty Conservation Institute, 2002), 3.

18 Cornelius Holtorf, “Is the Past a Non-Renewable Resource?” in Destruction and Conservation of Cultural Property, eds. Robert Layton, Peter Stone and Julian Thomas (London: Routledge, 2001), 266; Sully, 'Conservation Theory and Practice'. 
19 This is a general principle that shines through texts on values-based approaches, such as Avrami et al., Values and Heritage Conservation; de la Torre, ed., Assessing the Values of Cultural Heritage; Clavir, Preserving What is Valued; Muñas-Viñas, Contemporary Theory of Conservation

20 Smith, Uses of Heritage, 22

21 Harold Kalman, Heritage Planning Principle and Processes (New York \& Oxon: Routledge, 2014), 11.

22 The Australia ICOMOS Charter for the Conservation of Places of Cultural Significance (the Burra Charter) (Canberra: Australia ICOMOS, 1981), adopted 1979, last revision in 2013, http://australia.icomos.org/wp-content/uploads/The-Burra-Charter-2013-Adopted-31.10.2013.pdf (accessed July 7th, 2016). Notes on the Charter's review process are available as downloads from http://australia.icomos.org/publications/burra-charter-practice-notes/burra-charter-review-process/ (accessed July 12th, 2016).

23 See also James Semple Kerr, The Conservation Plan: A Guide to the Preparation of Conservation Plans for Places of European Cultural Significance (Sydney: National Trust, 1982), a document which outlines the logical processes of the Burra Charter now in its seventh edition: http://australia.icomos.org/wp-content/uploads/The-Conservation-Plan-7th-Edition.pdf (accessed July 7th, 2016).

24 cf. Michael Pearson \& Sharon Sullivan, Looking After Heritage Places: The Basics of Heritage Planning for Managers, Landowners and Administrators (Melbourne: Melbourne University Press, 1995); Australian Heritage Commission, Protecting Local Heritage Places, a Guide for Communities. (Canberra: Australian Heritage Commission, 2000); English Heritage, Conservation Principles Policies and Guidance for the Sustainable Management of the Historic Environment (London: English Heritage, 2008); Janet Stephenson, 'The Cultural Values Model: An Integrated Approach to Values in Landscapes,' Landscape and Urban Planning 84, no. 2 (2008).

25 See Avrami et al., Values and Heritage Conservation, and Pearson and Sullivan, Looking after Heritage Places, 165.

26 L. Harald Fredheim, 'Sustaining Places in Action: Facilitating Community Involvement in Heritage Stewardship by Co-Creation', in Landscape Values: Place and Praxis, ed. T. Collins, G. Kindermann, C. Newman and N. Cronin (Galway: Centre for Landscape Studies, NUI Galway, 2016), 115-121.

27 This point is made explicitly in Pearce, Archaeological Curatorship, 106 and is now being made for heritage processes in general in Rodney Harrison, "Beyond "Natural” and "Cultural” Heritage: Toward an Ontological Politics of Heritage in the Age of Anthropocene, Heritage \& Society 8, no. 1 (2015): 24-42.

28 See, for example, Ioannis Poulios, 'Moving beyond a Values-Based Approach to Heritage Conservation,' Conservation and Management of Archaeological Sites 12, no. 2 (2010): 170-185; Ioannis Poulios, The Past in the Present: A Living Heritage Approach - Meteora, Greece, (London: Ubiquity Press, 2014); Britta Rudolff, '”Intangible” and "tangible” Heritage: A Topology of Culture in Contexts of Faith' (PhD thesis, Johannes Gutenberg University of Mainz, 2006); Nigel Walter, 'From Values to Narrative: A New Foundation for the Conservation of Historic Buildings' International Journal of Heritage Studies 20, no. 6 (2013): 634-650.

29 Fig. 1 reproduces the graphic from Stephenson, 'The Cultural Values Model', 134. L. Harald Fredheim and Manal Khalaf, 'The Significance of Values: Heritage Value Typologies Re-Examined' 
International Journal of Heritage Studies 22, no. 6 (2016); Stephenson, 'The Cultural Values Model', 466 - 481. http://www.tandfonline.com/doi/pdf/10.1080/13527258.2016.1171247 (accessed June 5th, 2016).

30 cf. John Schofield, 'Being Autocentric: Towards Symmetry in Heritage Management Practices', in Valuing Historic Environments, ed. Lisanne Gibson and John Pendlebury (Farnham: Ashgate, 2009), 93-113; Rodney Harrison, Critical Approaches, (Abindon, Oxon: Routledge, 2013).

31 English Heritage, Conservation Principles: Policies and Guidance for the Sustainable Management of the Historic Environment, (London: English Heritage, 2008).

32 Fredheim and Khalaf, 'The Significance of Values’, 474.

33 Fredheim and Khalaf, 'The Significance of Values', 472-474.

$34 c f$. Denis Byrne, Helen Brayshaw, and Tracy Ireland, Social Significance: A Discussion Paper, $2^{\text {nd }}$ edit., (Hurstville, NSW: NSW National Parks and Wildlife Service, 2003).

35 Clavir makes reference to the material deterioration of sacred objects and the example of patina: Mirim Clavir, in Conservation: Principles, Dilemmas and Uncomfortable Truths, eds. Alison Richmond and Alison Bracker (London: Butterworth-Heinemann, 2009), 139-149.

36 cf. James Hales, 'Bats in Churches: Objective Assessment of Associated Damage Mechanisms' Archaeology International 17 (2014): 94-109; Matija Strlič et al. 'Damage Functions in Heritage Science,' Studies in Conservation 58, no. 2 (2013): 80-87.

37 Muñoz-Viñas, Contemporary Theory, 298.

38 There are ten primary 'agents of deterioration.' Nine were originally identified by Stefan Michalski at an International Institute for Conservation of Historic and Artistic Works (IIC) Canadian Group conference in 1987 in "Preventive Conservation: A Wall Chart". The ten agents are detailed on the Canadian Government's website: http://canada.pch.gc.ca/eng/1444330943476 (accessed July 5th, 2016). Robert Waller added the tenth in 1994, see: Robert R. Waller, 'Risk Management Applied to Preventive Conservation', in Storage of Natural History Collections: A Preventive Conservation Approach, ed. C. L. Rose, C. A. Hawks and H. H. Genoways (Iowa City, IA: Society for the Preservation of Natural History Collections, 1995), 21-27. See also, Stephan Michalski, 1994, 'A Systematic Approach to Preservation: Description and Integration with other Museum Activities', in Preventive Conservation, Theory and Research: Preprints of the Ottawa Congress, 12-16 September 1995, ed. A. Roy and P. Smith (London: IIC, 1994), 8-11.

39 See, for example, Joel Taylor and Siobhan Stevenson, 'Investigation Subjectivity within Collection Condition Surveys Museum Management and Curatorship 18, no. 1 (1999): 19-42; and Joel Taylor, 'Causes and Extent of Variation in Collection Condition Survey Data' Studies in Conservation 58, no. 2 (2013): 95-106.

40 cf. Sully, 'Conservation Theory and Practice.'

41 Fredheim and Khalaf, 'The Significance of Values', 467.

42 Muñoz-Viñas, Contemporary Theory, 298. 
43 cf. Fredheim and Khalaf, 'The Significance of Values' where the bibliography of relevant value typology frameworks is discussed before an updated framework to include intangible characteristics of heritage objects is proposed.

44 cf. Rudolff, ““Intangible” and “Tangible” Heritage’, 60.

45 See, for example, Rodney Harrison, Sarah Byrne, and Anne Clarke, eds Reassembling the Collection: Ethnographic Museums and Indigenous Agency (Sante Fe: SAR Press, 2013), 13.

46 cf. Katherine Clark, Informed Conservation: Understanding Historic Buildings and their Landscapes for Conservation (London: English Heritage, 2001).

47 Before the EU banned incandescent light bulbs in 2010, the Tinguely Museum purchased 80,000 bulbs for their collection of Jean Tinguely's light-based artworks. This solution does not ultimately solve the problem, but simply postpones it. See Reinhard Bek, 'Between Ephemeral and MaterialDocumentation and Preservation of Technology-based Works of Art,' in Inside Installations - Theory and Practice in the Care of Complex Artworks eds. Tatja Scholte and Glenn Wharton. (Amsterdam: Amsterdam University Press, 2011), 214; and Franziska Wagner, 'Light - A Hybrid Medium: Suggestions for the Documentation and Preservation of Artworks Based on Light Technology,' in Inside Installations-Theory and Practice in the Care of Complex Artworks eds. Tatja Scholte and Glenn Wharton (Amsterdam: Amsterdam University Press, 2011), 196.

48 On the intangible and artist intention see Wagner, 'Light - A Hybrid Medium,' 196-198.

49 See Albert Albano, 'Art in Transition,' in Historical and Philosophical Issues in the Conservation of Cultural Heritage eds. Nicholas Stanley Price, Mansfield Kirby Talley Jr and Alessandra Melucco Vaccaro, (Los Angeles: Getty Conservation Institute, 1996), 178-179.

50 Salvador Muñoz-Viñas, 'The Artwork that Became a Symbol of itself: Reflections on the Conservation of Modern Art,' in Theory and practice in the conservation of modern and contemporary art: reflections on the roots and the perspectives: proceedings of the international symposium held 13-14 January 2009 at the University of Applied Sciences and Arts, Faculty Preservation of Cultural Heritage, Hildesheim eds. Ursula Schädler-Saub and Angela Weyer. (London: Archetype, 2009), 17.

51 See, for example, Pip Laurenson, "The Management of Display Equipment in Time-based Media Installations” Tate Papers 3 (Spring 2005) http://www.tate.org.uk/research/publications/tatepapers/03/the-management-of-display-equipment-in-time-based-media-installations (accessed May 18th 2016); Modern Art: Who Cares? eds. Ijsbrand Hummelen and Dionne Sillé (London: Archetype Publications, 2005); Reinhard Bek, 'Preserving Moving Sculptures - Between Material and Ephemeral,' presentation at the Summer Institute in Technical Art History, Conservation Center at the Institute of Fine Arts, New York University, June 13, 2013; Oscar Chiantore and Antonio Rava,. Conserving Contemporary Art: Issues, Methods, Materials, and Research. (Los Angeles: Getty Conservation Institute, 2013).

52 In a recent presentation, Albrect Gumlich called for the creation of a material archive for kinetic collections, i.e., the storage of components that have been removed from kinetic works during their maintenance. Gumlich also suggested replacing components before they break so that the archive is of working material. Albrecht Gumlich. 'Ravages of Time: Zahn der Zeit: Gearing Towards Ends,' presentation at the 'Keep it Moving? Conserving Kinetic Art' conference, Milan, Italy, June 30th-July 2nd, 2016. 
Fig. 1. Overview of the Cultural Values Model, showing the reciprocity between values. The model envisages heritage as a large range of singular aspects grouped into three categories. These integrate expert and non-expert interpretations of heritage, reducing the likelihood of overlooking significant aspects of an object. Importantly, while practices and relationships tend to be intangible, they are linked to the physical forms of objects.

Fig. 2. The new UCL documentation template for treatment proposals - fields are explained and referred to within the text.

Fig. 3. The new UCL documentation template for treatment records - fields are explained and referred to within the text.

Table 1. Materials-, values-, and peoples-based conservation approaches in brief.

\begin{tabular}{|c|c|c|c|}
\hline & $\begin{array}{l}\text { Materials-based } \\
\text { conservation }\end{array}$ & $\begin{array}{l}\text { Values-based } \\
\text { conservation }\end{array}$ & $\begin{array}{l}\text { Peoples-based } \\
\text { conservation }\end{array}$ \\
\hline Values & Universal values & Stakeholder values & Community values \\
\hline $\begin{array}{l}\text { Supporting } \\
\text { documents }\end{array}$ & $\begin{array}{l}\text { Athens Charter of 1931, } \\
\text { Venice Charter 1964, } \\
\text { World Heritage } \\
\text { Convention } 1972\end{array}$ & $\begin{array}{l}\text { Burra charter } 1979 \text {, } \\
\text { Nara Document on } \\
\text { Authenticity } 1994\end{array}$ & $\begin{array}{l}\text { The Convention for the } \\
\text { Safeguarding of the } \\
\text { Intangible Cultural } \\
\text { Heritage } 2003 \\
\text { FAR0 Convention } 2005\end{array}$ \\
\hline Structure & $\begin{array}{l}\text { Expert-led, top-down, } \\
\text { linear decision-making }\end{array}$ & $\begin{array}{l}\text { Expert-led, top-down } \\
\text { decision-making, seeks } \\
\text { stakeholder participation, } \\
\text { consultation and dialogue }\end{array}$ & $\begin{array}{l}\text { Community led decision- } \\
\text { making, people-up, seeks } \\
\text { local solutions to } \\
\text { participation and } \\
\text { negotiation }\end{array}$ \\
\hline $\begin{array}{l}\text { Source of } \\
\text { values }\end{array}$ & $\begin{array}{l}\text { Heritage has 'intrinsic } \\
\text { value' decoded by } \\
\text { experts }\end{array}$ & $\begin{array}{l}\text { Heritage values are } \\
\text { ascribed by experts in } \\
\text { consultation with } \\
\text { stakeholders }\end{array}$ & $\begin{array}{l}\text { Heritage values are } \\
\text { context specific, defined } \\
\text { by contemporary } \\
\text { communities }\end{array}$ \\
\hline Significance & $\begin{array}{l}\text { Cultural significance } \\
\text { based on expert values }\end{array}$ & $\begin{array}{l}\text { Cultural significance } \\
\text { guided by expert values } \\
\text { that includes stakeholder } \\
\text { values }\end{array}$ & $\begin{array}{l}\text { Cultural significance is } \\
\text { determined by } \\
\text { community values }\end{array}$ \\
\hline $\begin{array}{l}\text { Relation to } \\
\text { material fabric }\end{array}$ & $\begin{array}{l}\text { The welfare of the } \\
\text { material heritage takes } \\
\text { precedence over } \\
\text { contemporary needs of } \\
\text { people }\end{array}$ & $\begin{array}{l}\text { The welfare of the } \\
\text { material heritage is } \\
\text { balanced with } \\
\text { contemporary needs of } \\
\text { stakeholders, but } \\
\text { material heritage remains } \\
\text { the primary concern }\end{array}$ & $\begin{array}{l}\text { The welfare of } \\
\text { contemporary } \\
\text { communities takes } \\
\text { precedence over material } \\
\text { heritage. }\end{array}$ \\
\hline $\begin{array}{l}\text { Main } \\
\text { conservation } \\
\text { decision- } \\
\text { making tool }\end{array}$ & $\begin{array}{l}\text { Conservation action is } \\
\text { guided by a condition } \\
\text { assessment }\end{array}$ & $\begin{array}{l}\text { Conservation action is } \\
\text { guided by a statement of } \\
\text { significance (includes } \\
\text { condition assessment, }\end{array}$ & $\begin{array}{l}\text { Conservation action is } \\
\text { guided by locally } \\
\text { appropriate references } \\
\text { (e.g. vision statement) }\end{array}$ \\
\hline
\end{tabular}




\begin{tabular}{|l|l|l|l|}
\hline & & $\begin{array}{l}\text { values assessment and } \\
\text { assessment of } \\
\text { management context) }\end{array}$ & \\
\hline $\begin{array}{l}\text { Treatment } \\
\text { results }\end{array}$ & The True object & The Expected object & The Plausible object \\
\hline
\end{tabular}

Table 2. The proposed UCL classification of significance according to four different classes of values.

\section{Evidentiary significance}

Aspects of value that provide evidence.

Heritage is often valued for its potential to provide evidence for research or display.

This may relate to the shape of an object or object feature, its material composition, the way it was constructed, how it has changed since its manufacture, etc.

\section{Sensory significance}

Aspects of value that are pleasing to the senses.

The identification of sensory aspects of value is perhaps the clearest with regard to intangible heritage.

\section{Associative significance}

Aspects of value that are important by association.

Things often become heritage because they are associated with people, other objects, events, practices or ideas that are of cultural significance.

\section{Functional significance}

Aspects of value that perform a function.

The functions heritage performs can be valued as evidence, by association or for pleasing the senses, but also for the function itself.

A function can be the very reason for why something is considered heritage. 


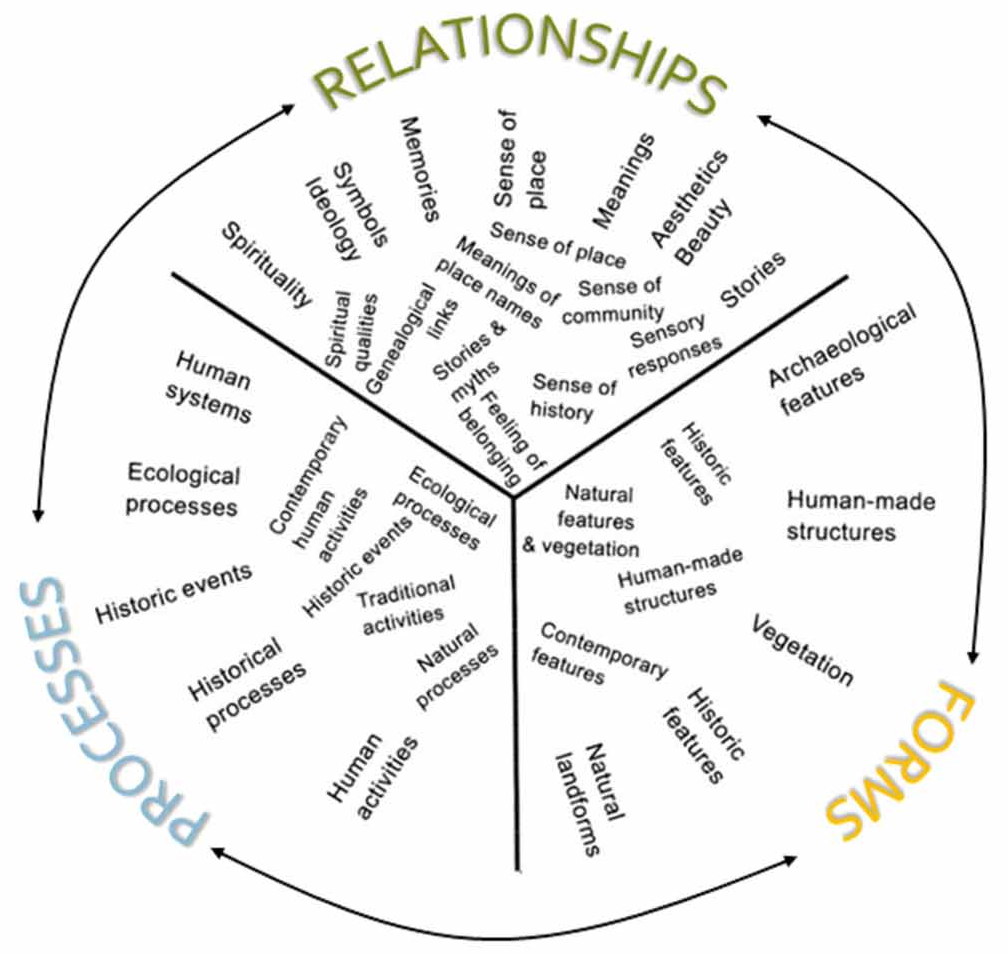




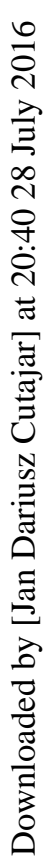
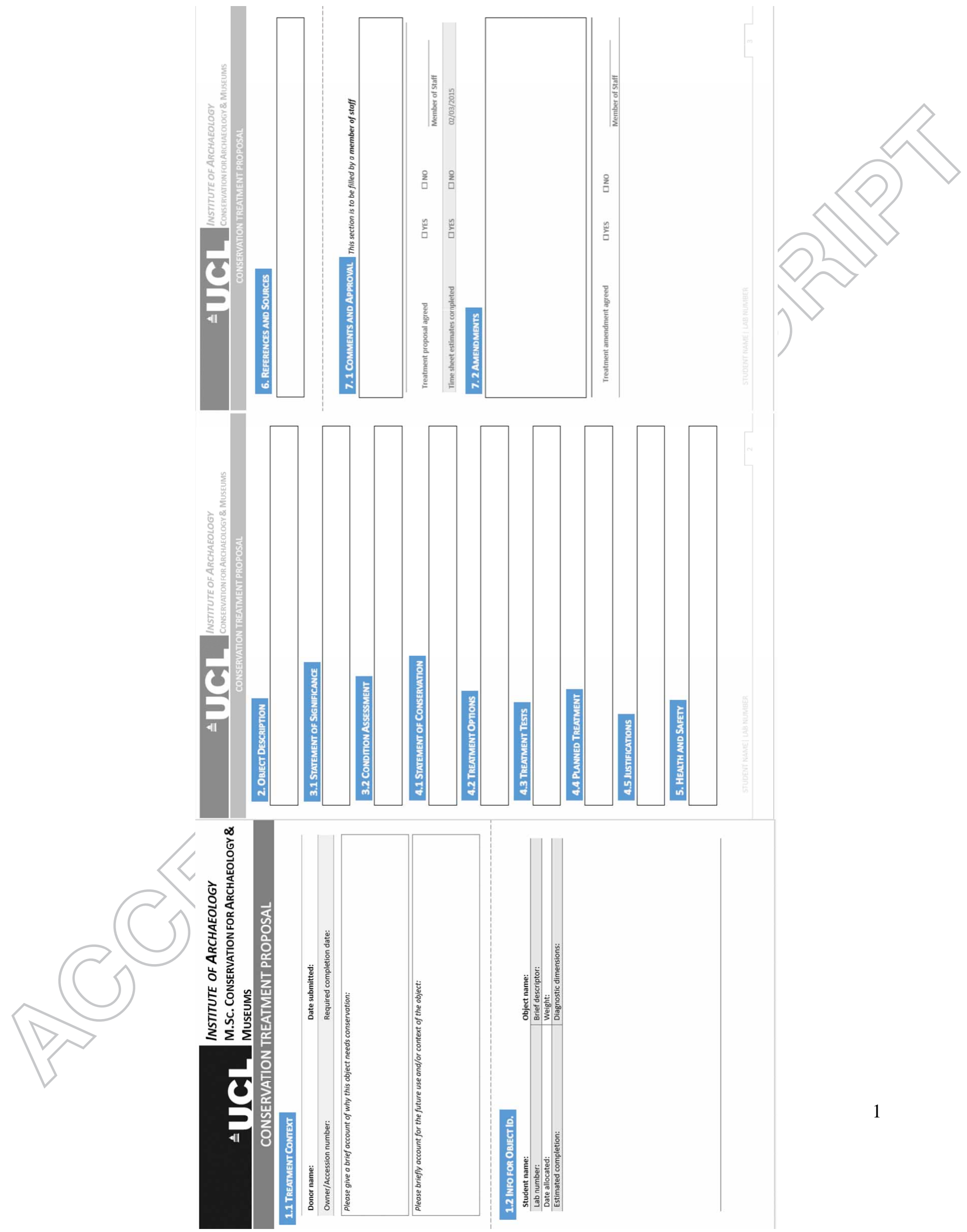


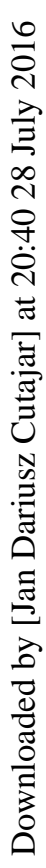
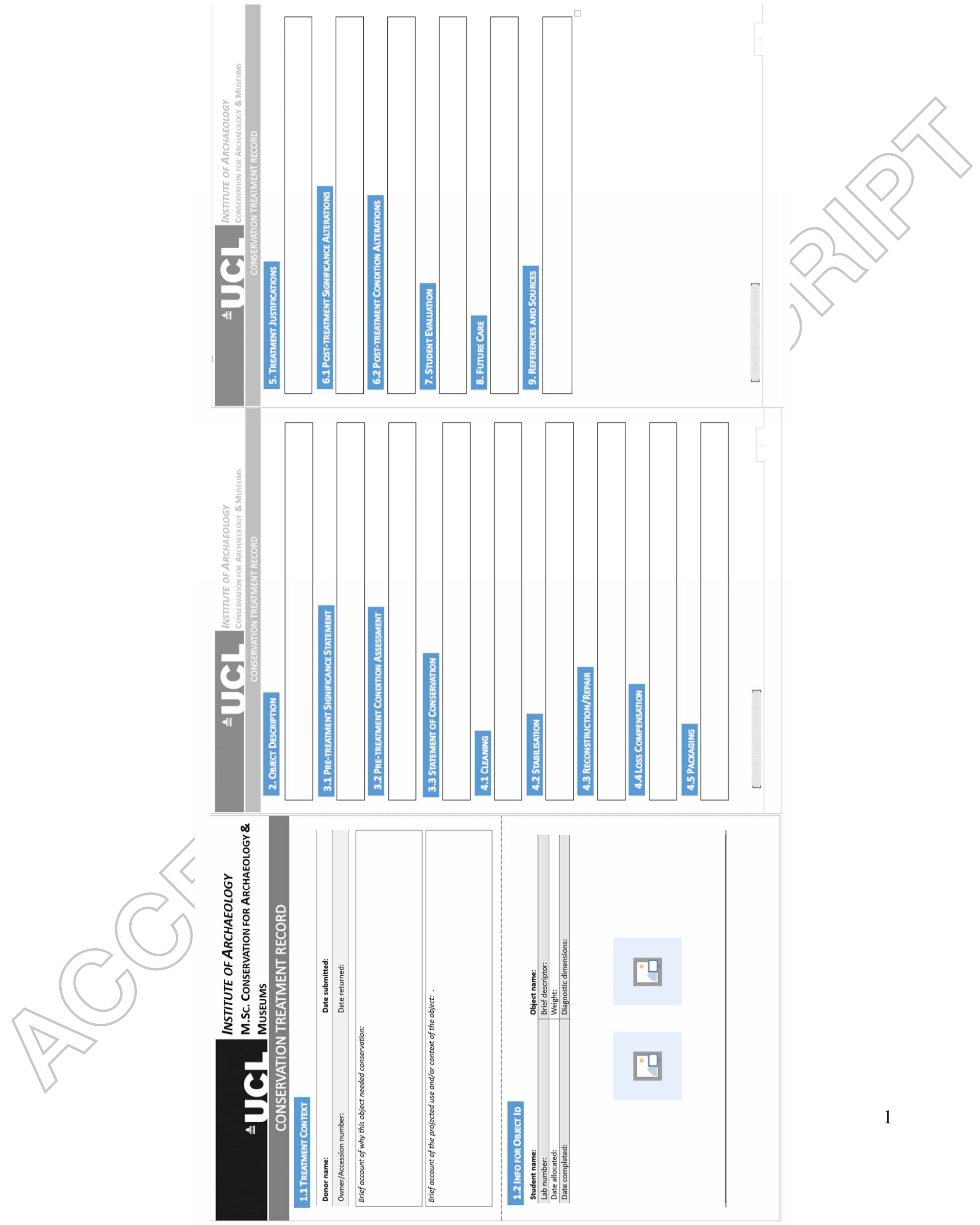